The references quoted in this article are mainly to recent contributions and to review articles; lack of space precludes a more comprehensive bibliography.

'Symp. Soc. Gen. Microbiol., "Bacterial Anatomy”, edit. E. T. C. Spooner and B. A. D. Stocker (Camb. Univ. Press, 1956) and Moyle, J., 150. (d) McQuillen, K., 127. (e) Tomcsik, J., 41. ${ }^{2}$ Cummins, C. S., Int. Rev. Cytol., 5, 25 (1956).

${ }^{3}$ Strange, R. E., and Powell, J. F., Biochem. J., 58, 80 (1954).

- Strange, R. E., Biochem. J., 64, $23 P$ (1956).

${ }^{5}$ Work, E., and Dewey, D. L., J. Gen. Microbiol., 9, 394 (1953).

- Hoare, D. S., and Work, E., Biochem. J., 65, 441, 448 (1957).

'Newton, B. A., Bact. Rev., 20, 14 (1956).

${ }^{8}$ Cummins, C. S., and Harris, H., J. Gen. Microbiol., 14, 583; 15. ix (1956); Int. Bull. Bact. Nomen. Tax., 6, 111 (1956).

- Jesaitis, M. A., and Goebel, W. F., Nature, 172, 622 (1953).

${ }^{10}$ Koch, G., and Weidel, W., Z. physiol. Chem., 303, 213 (1956).

11 Tomesik, J., and Baumann-Grace, J. B., Verh. Naturf. Ges. Basel, $\mathbf{6 7}, 218$ (1956). Vennes, J. W., and Gerhardt, P., Science, 124,

${ }^{22}$ Koch, G., and Weidel, W., Z. Naturforsch., 11b, 345 (1956).

${ }^{18}$ Strange, R. E., and Dark, F. A., Biochem. J., 62, 459 (1956); J. Gen. Microbiol., 16, 236 (1957).

${ }^{14}$ Meadow, P., Hoare, D. S., and Work, E., Biochem. J., 66, 270 (1957).

15 Toennies, G., and Gallant, D. L., J. Biol. Chem., 177, 831 (1949).
${ }^{16}$ Liebermeister, K., and Kellenberger, E., Z. Naturforsch.. $11 b 200$ (1956).

${ }^{17}$ Lederberg, J., Proc. U.S. Nat. Acad. Sci., 42, 574 (1956); J. Bact., 73, 144 (1957). ${ }^{18}$ Zinder, N. D., and Arndt, W. F., Proc. O.S. Nat. Acad. Sci., 42,

19 Park, J. T., J. Biol. Chem., 194, 877, 885, 897 (1952). Park, J. T., and Strominger, J. L., Science, 125, 99 (1957).

${ }^{20}$ Mitchell, P., and Moyle, J., J. Gen. Microbiol., 5, 421, 981 (1951): 10. 533 (1954).

${ }^{21}$ Asselineau, J., "Progr. Explor. Tuberc.", 5, 1 (S. Karger Bale, New York, 1952)

${ }^{22}$ McCarty, M., J. Exp. Med., 96, 555 (1952).

${ }^{29}$ Colover, J., and Consden, R., Nature, 177, 749 (1956).

24 Repaske, R., Biochim. Biophys. Acta, 22, 189 (1956)

${ }^{28}$ Richmond, M. H. J, Gen Microbiol, 18, iv (1957).

${ }^{26}$ Salton, M. R. J., and Ghuysen, J. M., Biochim. Biophys. Acta, 124, 160 (1957).

${ }^{27}$ Salton, M. R. J., Biochim. Biophys, Acta, 22, 495 (1958).

${ }^{28}$ Ingram, V. M., and Salton, M. R. J., Biochim. Biophys. Acta (in the press).

${ }^{29}$ Mitchell, P., and Moyle, J., J. Gen. Microbiol., 16, 184 (1957).

Strange, R. E., and Thorne, C. B., Biochim. Biophys. Acta, 24, 199 (1957).

31 Powell, J. F., and Strange, R. E., Biochem, J, 65, 700 (1957).

ss Ikawa, M., and Snell, E. E., Biochim. Biophys. Acta, 19, 576 (1955).

\title{
OBITUARIES
}

\section{Dr. L. F. Spath, F.R.S.}

WiTH the death of Leonard Frank Spath, which occurred on March 2 at the age of seventy-four, there has passed from the scene a palæontologist whose reputation was world-wide. Spath was born and educated in South Africa. It was not, however, until he had settled in England that an ambition to devote his life to the study of fossils came within sight of realization. Deriving the means of sustenance from the profession of commercial artist, he began to study for a degree, and in 1912, at the age of thirty, passed the external B.Sc. examination of the University of London with first-elass honours in geology. Meanwhile, he gained field-experience in Newfoundland (1910) and 'Tunis (1912) as a member of mineral prospecting parties. On the second expedition he collected ammonites described in the following year in his first paper.

Spath was given intermittent employment in the Geological Department of the British Museum (Natural History) during 1912-15, served in the Army during 1916-19, and settled down in the Museum finally on demobilization. He declined, however, the offer of an established post, and worked at South Kensington in the mornings and as an unestablished lecturer at Birkbeck College in the evenings. Papers and monographs, covering ammonites from all three Mesozoic systems, now began to flow from his pen, until eventually their number exceeded 130. Most important among them are his monographs on the Gault Ammonoidea (Palæontographical Society, 1923-43) and on the Jurassic Cephalopod Fauna of Cutch (Palaeontologia Indica, 1927-33), and his catalogues, published by the British Museum (Natural History) of Triassic Ammonoidea $(1934,1951)$ and of the Liassic family Liparoceratidae (1938). His general conclusions on ammonite evolution were summarized in 1933 ( $\mathrm{Biol}$. Rev. Camb. Phil. Soc., 8, 418) and 1936 (Pal. Zeitschr., $18,156)$. He was unable to accept the theory of recapitulation, applied to ammonites by Hyatt and his followers. Spath's intimate knowledge of the vast literature of his subject and his memory for the slight morphological differences serving for specific and even generic discrimination in the ammonites were equally remarkable. His style was found somewhat heavy by most readers; but ammonites, he always maintained, were a subject only for the seriously minded.

Spath was so constantly absorbed in his work that it is not surprising that he found little time for other activities, and was rarely, if ever, seen at social functions or even at meetings of learned societies. In his evening capacity of university lecturer he was a painstaking and lucid teacher, much liked by his students. In the Museum, also, he gave unstinted help to younger workers and visitors from overseas. He was elected a Fellow of the Royal Society in 1940, received in 1945 the Lyell Medal of the Geological Society of London, and was elected in 1951 a member of the Royal Danish Academy of Sciences. L. R. Cox

\section{Prof. H. Spenser-Gregory}

Dr. H. SPENSER-GRegory joined the physics staff of the Imperial College of Science and Technology as a lecturer in 1919, following a period of teaching at Saffron Walden Grammar School. Although his first degree had been in zoology and botany, Dr. Gregory soon showed he had a flair for experimental physics, which was made evident both in his contact with research and with teaching. In the former he initiated under the general guidance of Prof. Callendar a small but active research school on the measure. ment of the thermal conductivity of gases under various physical conditions. His later research interest had been in the instrumentation side of hygrometry. Assist. Prof. Gregory will be remembered by the many physics undergraduates who took his course for the enthusiastic spirit he created for the subject in the lecture room and in the laboratory alike. His outside interests were golf, association football and motoring. Since his retirement, Dr. Gregory had been engaged on writing a book on hygrometry, which was published only a few months before his death.
R. W. B. Stephens 